\title{
Amyloid- $\beta$ Increases Metallo- and Cysteine Protease Activities in Human Macrophages
}

\author{
José Castellano Lina Badimon Vicenta Llorente-Cortés \\ Cardiovascular Research Center CSIC-ICCC, IIB-Sant Pau, Hospital de la Santa Creu i Sant Pau, Barcelona, Spain
}

\section{Key Words}

Macrophages - Metalloproteinases - Cathepsin S .

Transforming growth factor- $\beta 1 \cdot$ Atherosclerosis

\begin{abstract}
Background/Aims: Amyloid- $\beta(A \beta)$ plays a crucial role in the onset and progression of atherosclerosis. Macrophages are a source of matrix metalloproteinases (MMPs), cysteine proteases and transforming growth factor (TGF)- $\beta 1$ in the vascular wall. The aims of this study were to analyze the capacity of $A \beta$ peptide (1-40) $(A \beta 40), A \beta$ peptide (1-42) $(A \beta 42)$ and fibrillar $A \beta 42$ (fA $A 42$ ) to modulate the expression and activity of MMP-9, MMP-2 and tissue inhibitor of MMP-1 (TIMP-1) in human monocyte-derived macrophages (HMDM). Additionally, we analyzed whether $A \beta$ internalization alters the secretion of cathepsin S (CatS) and TGF- $\beta 1$ by macrophages. Methods: HMDM were exposed to native and fibrillar $A \beta$. MMPs and TIMP-1 expression was analyzed by real-time PCR, and MMP abundance by zymography. Protein levels of precursor and active forms of CatS were analyzed by Western blot and TGF- $\beta 1$ levels by ELISA. Results: $A \beta 40, A \beta 42$ and especially $f A \beta 42$ strongly induced MMP-9/MMP-2 levels. Moreover, we showed enhanced active CatS and reduced TGF- $\beta 1$ protein levels in the secretome of $A \beta 42$ and $f A \beta 42-$
\end{abstract}

exposed macrophages. Conclusions: $A \beta$ can regulate the proinflammatory state of human macrophages by inducing metallo- and cysteine protease levels and by reducing TGF- $\beta 1$ secretion. These effects may be crucial in atherosclerosis progression.

(c) 2013 S. Karger AG, Basel

\section{Introduction}

Amyloid- $\beta$ (A $\beta$ ) peptides refer to amyloid precursor protein (APP)-derived peptides. APP is a transmembrane protein expressed by neurons and astrocytes that is rapidly metabolized by two pathways, namely a nonpathogenic nonamyloidogenic pathway and an $\mathrm{A} \beta$-synthesizing amyloidogenic pathway [1]. This amyloidogenic pathway is initiated by sequential cleavage of APP through $\beta$ - and $\gamma$-secretases [2]. $\beta$-Secretase cleavage occurs 16 amino acid (aa) residues toward the amino terminal of the $\alpha$-secretase cleavage site, between residues APP671 and APP672, generating soluble APP (sAPP) sAPP $\beta$ [3]. $\gamma$-Secretase cleavage at positions APP712 and APP713 generates 40 aa-long peptides (A $\beta 40)$, while cleavage at APP714 results in 42 aa-long peptides $(\mathrm{A} \beta 42)$. A $\beta$ peptides are amphiphilic 38-43 aa peptides as the first 28 aa

\section{KARGER}

E-Mail karger@karger.com www.karger.com/jvr
(C) 2013 S. Karger AG, Basel

1018-1172/13/0511-0058 $\$ 38.00 / 0$
Dr. Vicenta Llorente-Cortés

Cardiovascular Research Center, CSIC-ICCC, IIB-Sant Pau

Hospital de la Santa Creu i Sant Pau, Sant Antoni Maria Claret, 167

ES-08025 Barcelona (Spain)

E-Mail cllorente@csic-iccc.org 
residues are polar while the remaining residues are nonpolar [4]. These chemical characteristics make these peptides highly prone to aggregation $[5,6]$. The accumulation of amyloid fibrils leads to amyloid plaque formation in Alzheimer's disease. However, fibrillar amyloid species are also present in aortic atherosclerotic lesions [7]. In atherosclerotic plaques, amyloid can derive from diverse proteins that lose their native conformation, acquire predominantly $\beta$-sheet structure, and increase their propensity to aggregate. These proteins include several members of the apolipoprotein family such as apolipoprotein AI, apoA-I, apolipoprotein AII, apoA-II, apolipoprotein A-IV, ApoA-IV, apolipoprotein E, apoE, and serum amyloid $\mathrm{A}$, as well as alfa ${ }_{1}$-antitrypsine. The amyloid form localized in the arterial wall derives from an integral fragment of smooth muscle cell-produced lactadherin, termed medin [8], and from Apo-AI derived from the plasma high-density lipoprotein [9]. Besides these proteins, tropoelastin can also give rise to amyloidogenic elastin-derived peptides when it breaks down [10-12]. $\mathrm{A} \beta 40$ peptides are predominant species in atherosclerotic aortas [13] while both $A \beta 40$ and $A \beta 42$ are abundant in the brain. $A \beta 42$ is less soluble and is present in all types of senile plaques, whereas $A \beta 40$ is the major species deposited in the cerebral blood vessels [14-17]. A $\beta$ interacts with a wide variety of proteins including APP, NMDA receptors, integrins, $\alpha 7$ nicotinic acetylcholine receptors, a7nAchR, p75 neurotrophin receptors, p75NTR, collagen-like Alzheimer amyloid plaque component precursor/collagen type XXV, CLAC-P/ColXXV, the receptor for advanced glycosylation end products, RAGE, serpinenzyme complex receptor, SEC-R, insulin receptors, scavenger receptors and heparan sulfate proteoglycans [18]. Most of these interactions are pathological for the cells. It has been previously reported that macrophages have the ability to internalize and degrade $A \beta$ in an apoEfacilitated manner [19]. These authors suggested that macrophage-mediated $A \beta$ degradation is, in part, mediated by secretion of matrix metalloproteinase-9 (MMP9). The degradation of $A \beta$ by macrophages is an essential physiological mechanism to limit $\mathrm{A} \beta$ accumulation within brain parenchyma and blood vessels [20]. However, an excess of metalloproteinase activity may contribute to extracellular matrix remodeling and the onset of acute thrombotic complications [21-24]. Among the proteases, MMP-9 and MMP-2 have the capacity to cleave integral membrane APP to form A $\beta$ peptides [20]. In addition, other proteases that are abundant in atherosclerotic lesions, including cathepsins B, K, L and S may cleave apolipoproteins to generate intermediate-sized fragments that form amyloid [25]. Macrophages express cathepsin $S$ (CatS) $[26,27]$ and intracellular CatS activity increases in response to proinflammatory cytokines such as interferon- $\gamma$-modulating MHC class II maturation [28, 29]. Remarkably, CatS levels are reportedly increased in atherosclerosis [30]. Reduced transforming growth factor (TGF)- $\beta 1$ activity/signaling is also a feature of atherosclerosis, as evidenced by low TGF- $\beta$ levels in vessel walls [31, 32] and in the plasma of patients with coronary artery disease $[33,34]$. On the basis that amyloid is present in atherosclerotic plaques and that macrophage-derived elastases in combination with MMPs play a crucial role in vascular extracellular matrix remodeling and atherosclerotic plaque stability, the aim of this study was to analyze the effect of $A \beta$ peptides - $A \beta(1-40)(A \beta 40), A \beta(1-42)$ $(\mathrm{A} \beta 42)$ and fibrillar $A \beta 42(\mathrm{fA} \beta 42)$ - on the expression and activity of MMP-9, MMP-2 and tissue inhibitor of MMP-1 (TIMP-1) in human monocyte-derived macrophages (HMDM). Additionally, we analyzed the effect of $\mathrm{A} \beta$ peptides on the levels of secreted active CatS and TGF- $\beta 1$.

\section{Methods}

$A \beta 40, A \beta 42$ and $f A \beta 42$ Preparation and Characterization $A \beta 40$ and $A \beta 42$ were purchased from rPeptide (Bogart, Ga., USA). For the solubilization of $A \beta 40$ and $A \beta 42$, lyophilized $A \beta$ peptides were dissolved at $10 \mathrm{mg} / \mathrm{ml}$ concentration in DMSO and then directly diluted into cell culture medium to the final treatment concentration. fA $\beta 42$ was prepared by incubating freshly solubilized $\mathrm{A} \beta 42$ peptide at $10 \mu \mathrm{M}$ in cell culture medium at $37^{\circ} \mathrm{C}$ for 7 days $[35,36]$. For transmission electron microscopy, $A \beta$ preparations were negatively stained with $2 \%$ uranyl acetate for $1 \mathrm{~min}$ and were observed under a Hitachi $600-\mathrm{AB}$ transmission electron microscope (Hitachi High Technologies America, Dallas, Tex., USA). Images were digitalized with a Gatan BioScan camera (Gatan, Pleasanton, Calif., USA).

\section{Isolation and Differentiation of HMDM}

Monocytes were obtained by standard protocols from buffycoats (35-40 ml) of healthy donors procured from the Blood and Tissue Bank of Barcelona. Cells were applied on $15 \mathrm{ml}$ of FicollPaque $^{\mathrm{TM}}$ Plus (GE Healthcare Life Sciences, Little Chalfont, UK) and centrifuged for $45 \mathrm{~min}$ at $400 \mathrm{~g}$ and $22^{\circ} \mathrm{C}$ with no break. In each experiment, macrophages were isolated from 2 different individuals and mixed. The same experimental setting was repeated three times (a total of 6 independent healthy subjects) with duplicates for each condition. Mononuclear cells were obtained from the central white band of the gradient, exhaustively washed in phosphate-buffered saline, and resuspended in RPMI medium (Gibco, Life Technologies, Carlsbad, Calif., USA) supplemented with $10 \%$ human serum AB (Lonza Group, Basel, Switzerland), $1 \%$ HEPES (Gibco) and antibiotics (Invitrogen, Life Technologies, Carlsbad, Calif., USA). Human serum AB was obtained from hu- 
man plasma blood type $\mathrm{AB}$ collected from healthy donors at FDAlicensed facilities located entirely within the USA. The fraction of mononuclear cells isolated by this procedure from fresh blood has been described to be more than 99\% pure [37]. Monocytes were allowed to differentiate into macrophages by addition of complete medium with $10 \%$ human serum AB for 5 days. HMDM were serum deprived several times, depending on the experimental set, before the incubation with DMSO alone (control) or with different concentrations of native or fibrillar $\mathrm{A} \beta 40$ or $\mathrm{A} \beta 42$. HMDM were then exhaustively washed and collected for mRNA/protein extraction. Cell culture media samples were stored at $-20^{\circ} \mathrm{C}$ for determination of TGF- $\beta 1$ concentrations.

\section{Immunocytochemistry}

HMDM were seeded onto glass coverslips, serum deprived, exposed to fluorescently-labeled fA $\beta 42$ (N-terminal FAM-labeled A 342 ; AnaSpec, Fremont, Calif., USA) $5 \mu \mathrm{M}$ for $4 \mathrm{~h}$, and finally fixed with $4 \%$ paraformaldehyde to analyze macrophages fA $\beta 42$ internalization. Solubilization of lyophilized FAM-labeled A $\beta 42$ and the obtainment of fibrillar forms were assessed as described above with unlabeled $A \beta$ peptides. Images of immunostained cells were analyzed on a Leica inverted fluorescence confocal microscope (Leica TCS SP2-AOBS, Wetzlar, Germany) with a $63 \times 1.4$ oil immersion objective and processed with the Leica Standard Software TCS-AOBS.

\section{RNA Extraction and cDNA Synthesis}

Total RNA was extracted from cultured HMDM cells using TriPure ${ }^{\mathrm{TM}}$ isolation reagent (Roche Applied Science, Rotkreuz, Switzerland) and purified with the RNeasy Mini Kit (Qiagen, Hilden, Germany) according to the manufacturer's instructions. Extracted RNA was eluted in $15 \mu$ of nucleases-free water. RNA yield and quality were assessed by agarose gel electrophoresis and spectrophotometry, and then stored at $-80^{\circ} \mathrm{C}$ until used. RNA was digested with DNase I (Invitrogen). For cDNA synthesis, $1.5 \mu \mathrm{g}$ of total RNA was used according to the protocol provided with the High Capacity cDNA Reverse Transcription kit (Applied Biosystems, Life Technologies, Carlsbad, Calif., USA). Recombinant RNasin Ribonuclease Inhibitor (Applied Biosystems) was added to prevent RNase-mediated degradation. The cDNA was stored at $-20^{\circ} \mathrm{C}$.

\section{Determination of Gene Expression by Real-Time PCR}

Gene expression analyses of MMP-9, MMP-2, TIMP-1 and CatS mRNA were performed at mRNA level by quantitative realtime reverse transcriptase PCR. We used the following assays-ondemand (Applied Biosystems): MMP-9(Hs00234597_m1), MMP2 (Hs00234422_m1), TIMP-1 (Hs01092511_m1) and CatS (Hs00175407_m1). 18S rRNA (4319413E) was used as a housekeeping gene. We mixed $2 \mu \mathrm{l}$ of single-stranded cDNA with $2 \mu \mathrm{l}$ of 20× TaqMan Gene Expression Assays for each assay-on-demand, $25 \mu$ of TaqMan Universal PCR Master Mix (Applied Biosystems), and $21 \mu \mathrm{l}$ of nucleases-free water. After gentle mixing, the mixture was transferred into a real-time PCR microplate. The real-time PCR microplate was sealed, centrifuged, and then placed in the sample block of an Applied Biosystems 7900 HT real-time PCR System. The thermal cycling conditions were $2 \mathrm{~min}$ at $50^{\circ} \mathrm{C}$ and 10 min at $95^{\circ} \mathrm{C}$, followed by 40 cycles of $15 \mathrm{~s}$ at $95^{\circ} \mathrm{C}$ and $1 \mathrm{~min}$ at $60^{\circ} \mathrm{C}$. Expression levels were measured in triplicate. The threshold cycle $(\mathrm{Ct})$ values were normalized to the housekeeping gene.

\section{Western Blot Analysis}

Blots were incubated with monoclonal antibodies against human CatS (sc-271619; Santa Cruz Biotechnology Inc., Santa Cruz, Calif., USA). CatS (E-3) is a mouse monoclonal antibody specific for an epitope mapping between aa 302-331 at the C-terminus of CatS of human origin and recognizes precursor $(37 \mathrm{kDa})$ and active $(24 \mathrm{kDa})$ forms. Phosphorylation state of signaling proteins including Pyk2 and ERK1,2 was analyzed by incubating blots with monoclonal antibodies against phospho-Pyk2 (p-Pyk2, No. 3291; Cell Signaling Technology, Danvers, Mass., USA) or against phospho-ERK1,2 (p-ERK1,2, No. 3480; Cell Signaling Technology). Blots were also exposed to total Pyk2 (No. 9101; Cell Signaling Technology) and total ERK1,2 (Assay Designs, KAP-MA001).

\section{Zymography}

MMP abundance was measured by gelatinolytic zymography of the cell culture medium. The cell medium was dialyzed against $0.01 \mathrm{M} \mathrm{NH}_{4} \mathrm{HCO}_{3}$ at $4^{\circ} \mathrm{C}$, lyophilized, and dissolved in RIPA buffer $(150 \mathrm{~mm} \mathrm{NaCl}, 1 \%$ Triton $\mathrm{X}-100,0.5 \%$ sodium deoxycholate, $0.1 \%$ SDS, 2 mM EDTA, 50 mM Tris- $\mathrm{HCl} \mathrm{pH} \mathrm{8)} \mathrm{supplemented} \mathrm{with}$ Complete Protease Inhibitor Cocktail (Roche Applied Science). Equal amounts of supernatants were subjected to SDS-PAGE in $10 \%$ polyacrylamide (Bio-Rad, Berkeley, Calif., USA) gels containing $1 \mathrm{mg} / \mathrm{ml}$ porcine skin type A gelatin (Sigma-Aldrich, St. Louis, Mo., USA) at $4{ }^{\circ} \mathrm{C}$. After electrophoresis, the substrate gels were soaked twice with $2.5 \%$ Triton X-100 (Sigma-Aldrich) for $15 \mathrm{~min}$ each at room temperature to remove SDS. The gels were then incubated in $50 \mathrm{mM}$ Tris- $\mathrm{HCl}, 10 \mathrm{mM} \mathrm{CaCl}_{2}$, and $0.02 \% \mathrm{~N}_{3} \mathrm{Na}$ for $20 \mathrm{~h}$ at $37^{\circ} \mathrm{C}$. Gel staining was performed with $0.5 \%$ Coomassie Brilliant Blue R-250 (Thermo Scientific Pierce, Rockford, Ill., USA) and then destained in 50\% 2-propanol, 1\% acetic acid (Panreac, Barcelona, Spain). Clear bands against the blue background indicated the presence of MMP abundance measured by densitometric scanning. Bands were quantified with a GS-800 calibrated imaging densitometer (Bio-Rad) using the Quantity-One 1-D Analysis Software (Bio-Rad). Results are expressed as arbitrary units that refer to units of intensity $\times$ millimeters.

\section{Determination of TGF- $\beta 1$ Levels in Cell Culture Media}

Samples from Human Macrophages

Cell culture media samples were thawed, centrifuged and used for determination of TGF- $\beta 1$ levels by ELISA (DGR Diagnostics, Marburg, Germany) according to the manufacturer's instructions. In brief, the neutralized standards and samples were added to the antibody-coated (polyclonal) microtiter wells. After the first incubation, the unbound sample material was removed by washing. Then a monoclonal mouse anti-TGF- $\beta 1$ antibody, a biotinylated anti-mouse IgG antibody and the Streptavidin-HRP enzyme complex were incubated in succession. An immuno-enzyme sandwich complex was formed. After incubation, the unbound conjugate was washed off. Having added the substrate solution, the intensity of color developed was proportional to the concentration of TGF- $\beta 1$ in the sample.

\section{Data Analysis}

Data were expressed as mean \pm SEM. A StatView (Abacus Concepts, Piscataway, N.J., USA) statistical package for the Macintosh computer system was used for all the analyses. Multiple groups were compared by ANOVA or Wilcoxon test as needed. Statistical significance was considered when $\mathrm{p}<0.05$. 

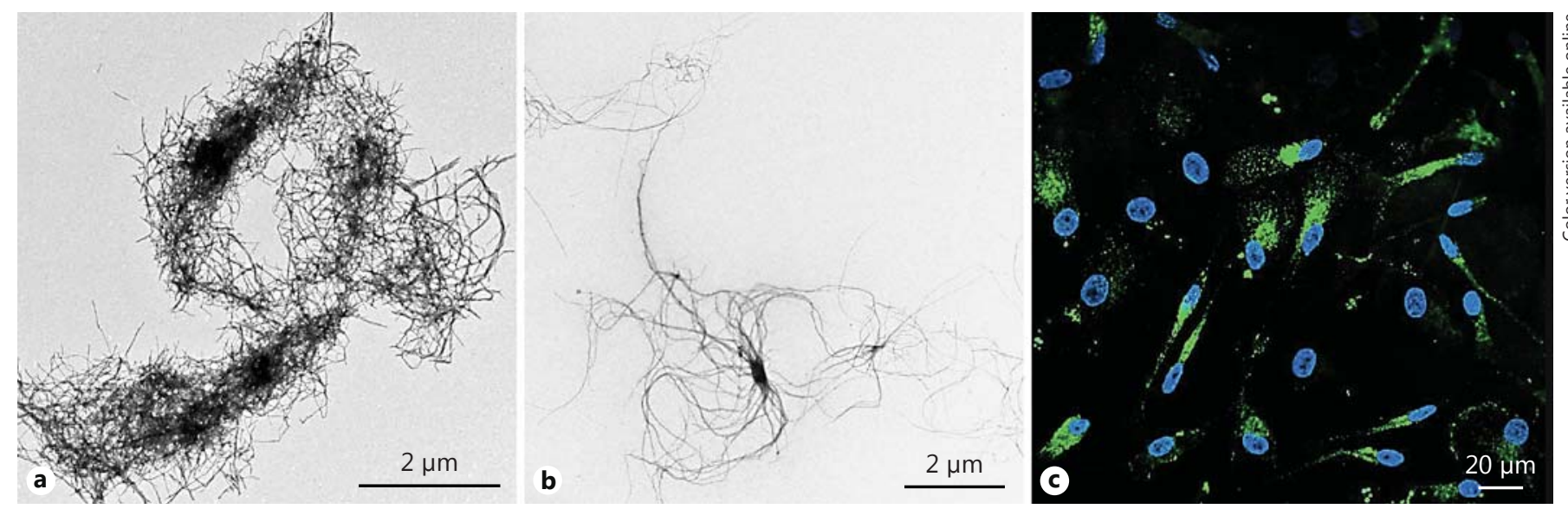

Fig. 1. Negative staining electron microscopy images of fibrillar $\mathrm{A} \beta 42$ (fA $\beta 42,5 \mu \mathrm{M} ; \mathbf{a})$ and freshly dissolved $\mathrm{A} \beta 42$ $(5 \mu \mathrm{M} ; \mathbf{b})$. c Confocal microscopy image of HMDM exposed to FAM-fA $\beta 42(5 \mu \mathrm{M})$ for $18 \mathrm{~h}$. Cytoplasmatic fA $\beta 42$ is shown in green and nuclei are shown in blue (colors refer to the online vesion only).

\section{Results}

Effects of $A \beta$ on MMP-9 and MMP-2 Expression and Activity in Human Macrophages

Uranyl acetate-negative images from electron microscopy revealed that fresh $\mathrm{A} \beta 42$ was transformed into insoluble amyloid fibrils after 7 days at $37^{\circ} \mathrm{C}$ (fig. 1a). In native preparations, filaments were rarely found and they were extremely small and thin (fig. 1b). Confocal microscopy experiments showed that FAM-labeled fA $\beta 42(5 \mu \mathrm{M}$, time $4 \mathrm{~h}$ ) was avidly taken up by human macrophages (fig. 1c). Real-time PCR experiments showed that $A \beta 40$ and $A \beta 42(5 \mu \mathrm{M}, 48 \mathrm{~h})$ increased MMP-9 mRNA to 1.99and 2.06-fold, respectively (fig. 2a). Zymography experiments (fig. 2b) showed that $A \beta 40$ and $A \beta 42(5 \mu \mathrm{M}, 48 \mathrm{~h})$ strongly increased MMP-9 abundance to 2.31-fold and to 2.76-fold, respectively. MMP-9 levels were not altered by exposure of HMDM to $A \beta 40$ or $A \beta 42$ for $12 \mathrm{~h}$ (data not shown).

A $\beta 40$ increased MMP- 2 mRNA expression and abundance by approximately 2 -fold independently of the tested dose (fig. $2 c$, d). In contrast, A $\beta 42$ increased MMP-2 mRNA expression in a dose-dependent manner, from 1.64 -fold at $0.01 \mu \mathrm{M}$ to 3.13 -fold at $5 \mu \mathrm{M}$ (fig. $2 \mathrm{c}$ ). In agreement with real-time PCR results, zymography experiments (fig. 2d) showed that MMP-2 abundance was strongly increased by 4.73 -fold in the presence of the highest $\mathrm{A} \beta 42$ dose $(5 \mu \mathrm{M})$. MMP-2 mRNA expression and abundance was not altered by exposure of HMDM to $A \beta 40$ or $A \beta 42$ for $12 \mathrm{~h}$ (data not shown). TIMP-1
mRNA expression was significantly decreased by the highest doses ( 1 and $5 \mu \mathrm{M}, 48 \mathrm{~h}$ ) of $\mathrm{A} \beta 40$ and $\mathrm{A} \beta 42$ (fig. 2e) without differences between the effect of $A \beta 40$ and $\mathrm{A} \beta 42$.

Since insoluble amyloid fibrils are crucial in the pathogenesis of Alzheimer's disease, we compared the effects of soluble and insoluble $A \beta$ peptides on MMP expression and activation. Our results show that $\mathrm{fA} \beta 42$ exerted a stronger upregulatory effect than A $\beta 42$ on both MMP-9 mRNA expression (2.9- vs. 2.3-fold, $\mathrm{p}<0.01)$ and MMP9 abundance (10.3 - vs. 6.7-fold, $\mathrm{p}<0.01$; fig. 3a, b). There were no significant differences between the effect of $A \beta 42$ and $\mathrm{fA} \beta 42$ on MMP- 2 mRNA expression or abundance (fig. 3c, d). A $\beta 42$ and $f A \beta 42$ also exerted a similar downregulatory effect on TIMP-1 mRNA expression in human macrophages (fig. 3e).

\section{Effect of A $\beta$ on Macrophage-Secreted Active CatS}

We explored the distribution of CatS in control and $\mathrm{A} \beta$-exposed macrophages. The precursor CatS form (37 $\mathrm{kDa}$ ) was detected in the cell-culture media but not in the whole macrophage lysates (fig. 4a). This secreted CatS precursor form was not altered by $\mathrm{A} \beta$. In contrast, the 24 $\mathrm{kDa}$ active Cat $\mathrm{S}$ form, detected in both cell lysates and cell culture media, was significantly altered by $A \beta$ (fig. $4 \mathrm{~b}$ ). While $A \beta 42$ and fA $\beta 42(5 \mu \mathrm{M}, 48 \mathrm{~h})$ significantly decreased the active cellular CatS, both $A \beta 42$ and $\mathrm{fA} \beta 42$ significantly increased the active secreted CatS. CatS mRNA levels were not significantly altered by macrophage exposure to $A \beta$ (data not shown). 

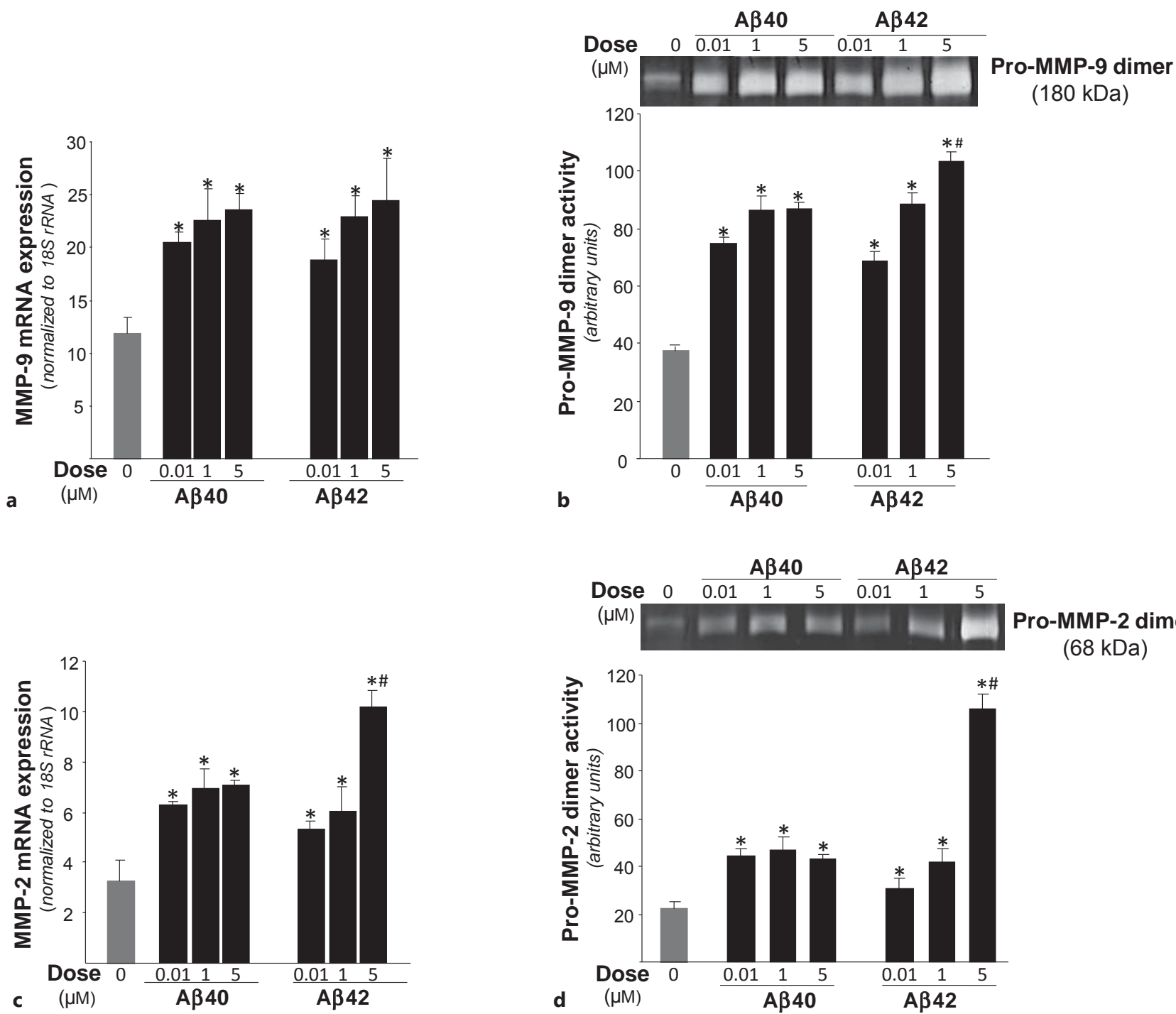

Pro-MMP-2 dimer

$(68 \mathrm{kDa})$

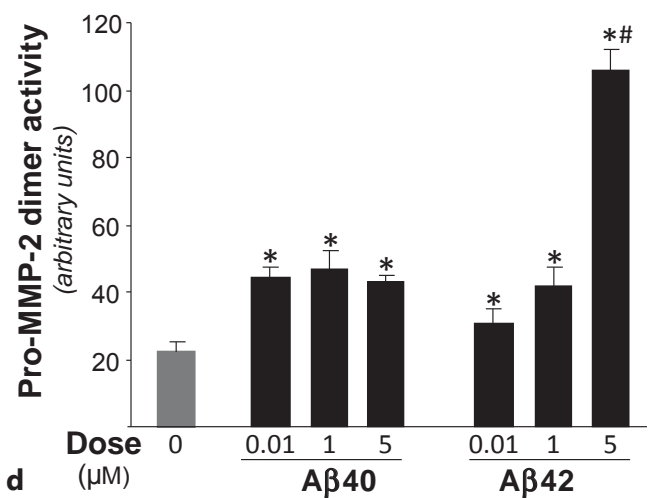

Fig. 2. Effect of A $\beta$ peptides on MMP-9 and MMP-2 expression and abundance in human macrophages. HMDM were treated with increasing doses $(0.01,1$ and $5 \mu \mathrm{M})$ of $\mathrm{A} \beta 40$ and $\mathrm{A} \beta 42$ for $48 \mathrm{~h}$. MMP-9 (a), MMP-2 (c) and TIMP-1 (e) mRNA expression, and MMP-9 (b) and MMP-2 (d) abundance was analyzed by real-time PCR and zymography, respectively. Real-time PCR data were processed with a specially designed software program based on $\mathrm{Ct}$ values of each sample and normalized to $18 \mathrm{~S}$ rRNA. Zymography bands were quantified and expressed as arbitrary units. Results are shown as mean \pm SEM of three independent experiments performed in duplicate. ${ }^{*} \mathrm{p}<0.05$ versus control cells (incubated in absence of $\mathrm{A} \beta) ;{ }^{\#} \mathrm{p}<0.05$ versus $\mathrm{A} \beta 40$-exposed HMDM.

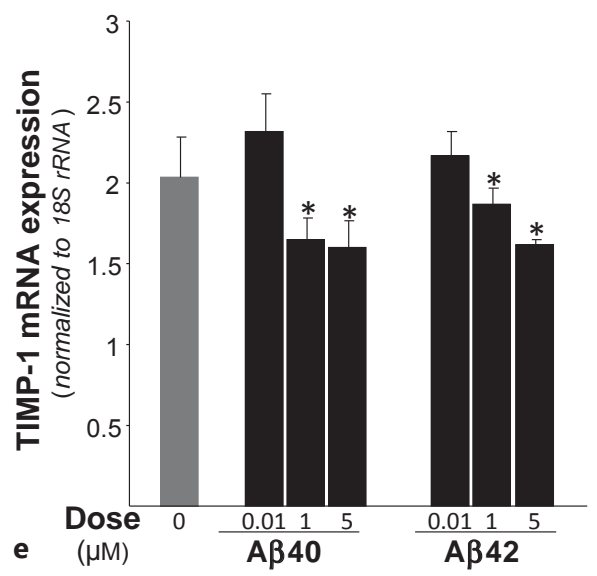




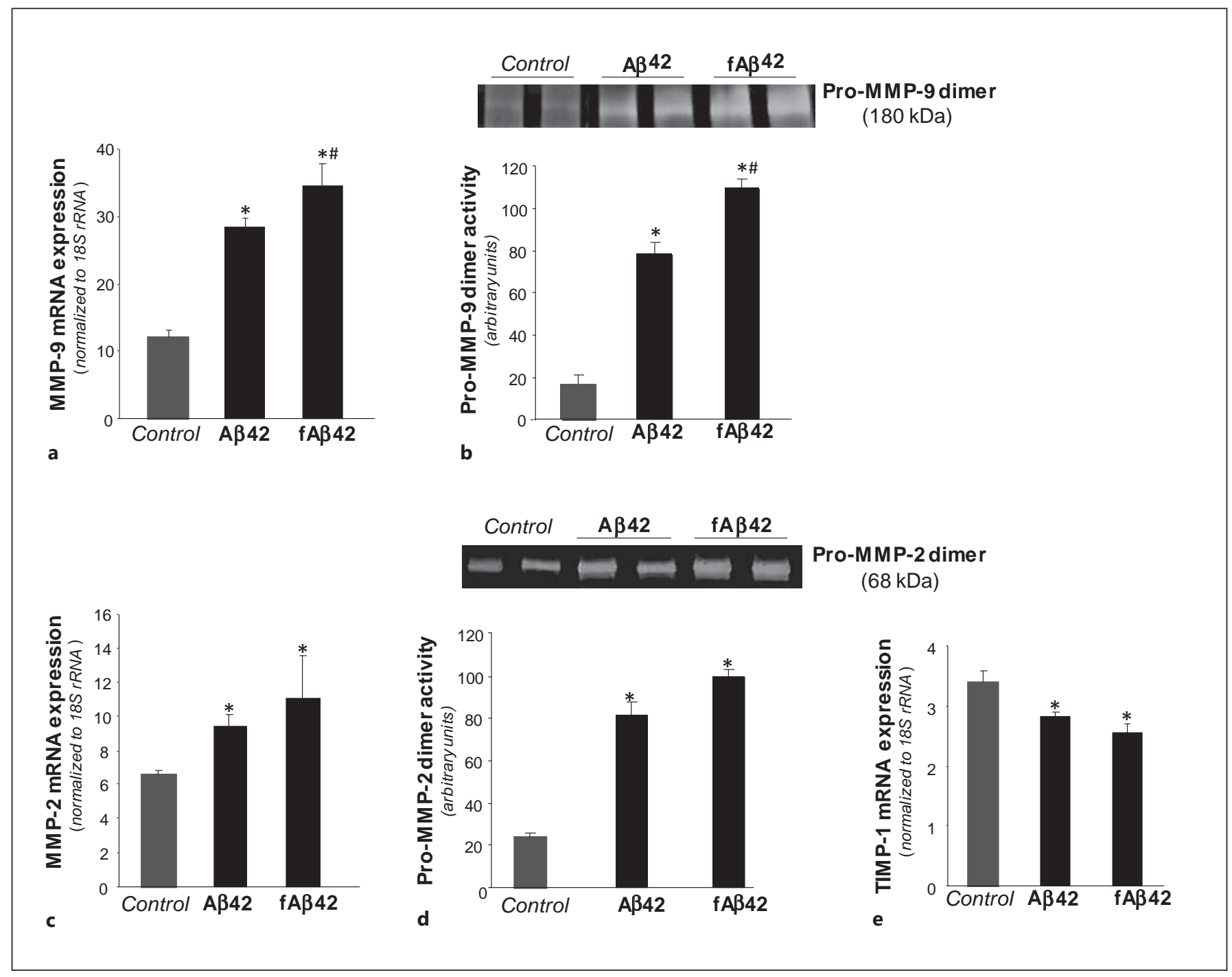

Fig. 3. Comparative effect of $A \beta 42$ and $f A \beta 42$ on MMP-9 and MMP-2 expression and abundance in human macrophages. HMDM were treated with $A \beta 42$ and $\mathrm{fA} \beta 42(5 \mu \mathrm{M})$ for $48 \mathrm{~h}$. MMP9 (a), MMP-2 (c) and TIMP-1 (e) mRNA expression, and MMP-9 (b) and MMP-2 (d) abundance was analyzed by real-time PCR and zymography, respectively. Real-time PCR data were processed with a specially designed software program based on Ct values of each sample and normalized to $18 \mathrm{~S}$ rRNA. Zymography bands were quantified and expressed as arbitrary units. Results are shown as mean \pm SEM of three independent experiments performed in duplicate. ${ }^{*} \mathrm{p}<0.05$ versus control cells (incubated in absence of $\mathrm{A} \beta 42) ;{ }^{*} \mathrm{p}<0.05$ versus $A \beta 42$-exposed HMDM.

\section{Effect of $A \beta$ on Pyk 2 and ERK1,2 Phosphorylation}

Western blot analysis showed that $A \beta$ induced a sustained phosphorylation of Pyk 2 at $48 \mathrm{~h}$ (fig. 5a) in human macrophages. fA $\beta 42$ exerted a stronger upregulatory effect than $A \beta 42$ on Pyk2 phosphorylation (3- vs. 2-fold, $\mathrm{p}<0.01)$. Total Pyk2 was not significantly altered by $A \beta 42$ or fA $\beta 42$ in human macrophages. ERK1,2 phosphorylation was also sustainably upregulated by $\mathrm{A} \beta$ at $24 \mathrm{~h}$ (fig. $5 b$ ) and the effect of $f A \beta 42$ was higher than that of
A $\beta 42$ (3.25-vs. 2.05-fold, $\mathrm{p}<0.01$ ). Total ERK1,2 protein levels were not affected by $A \beta 42$ or $\mathrm{fA} \beta 42$.

\section{Effect of $A \beta$ on Secreted TGF- $\beta 1$ Levels}

Both native and fibrillar forms of $A \beta 40$ and $A \beta 42$ at $5 \mu \mathrm{M}$ significantly reduced TGF $\beta 1$ levels in the secretome of human HMDM at $12 \mathrm{~h}$. At $48 \mathrm{~h}, \mathrm{fA} \beta 42$ exerted much higher downregulatory effect on secreted TGF- $\beta 1$ levels than the other $A \beta$ forms (fig. 6). 


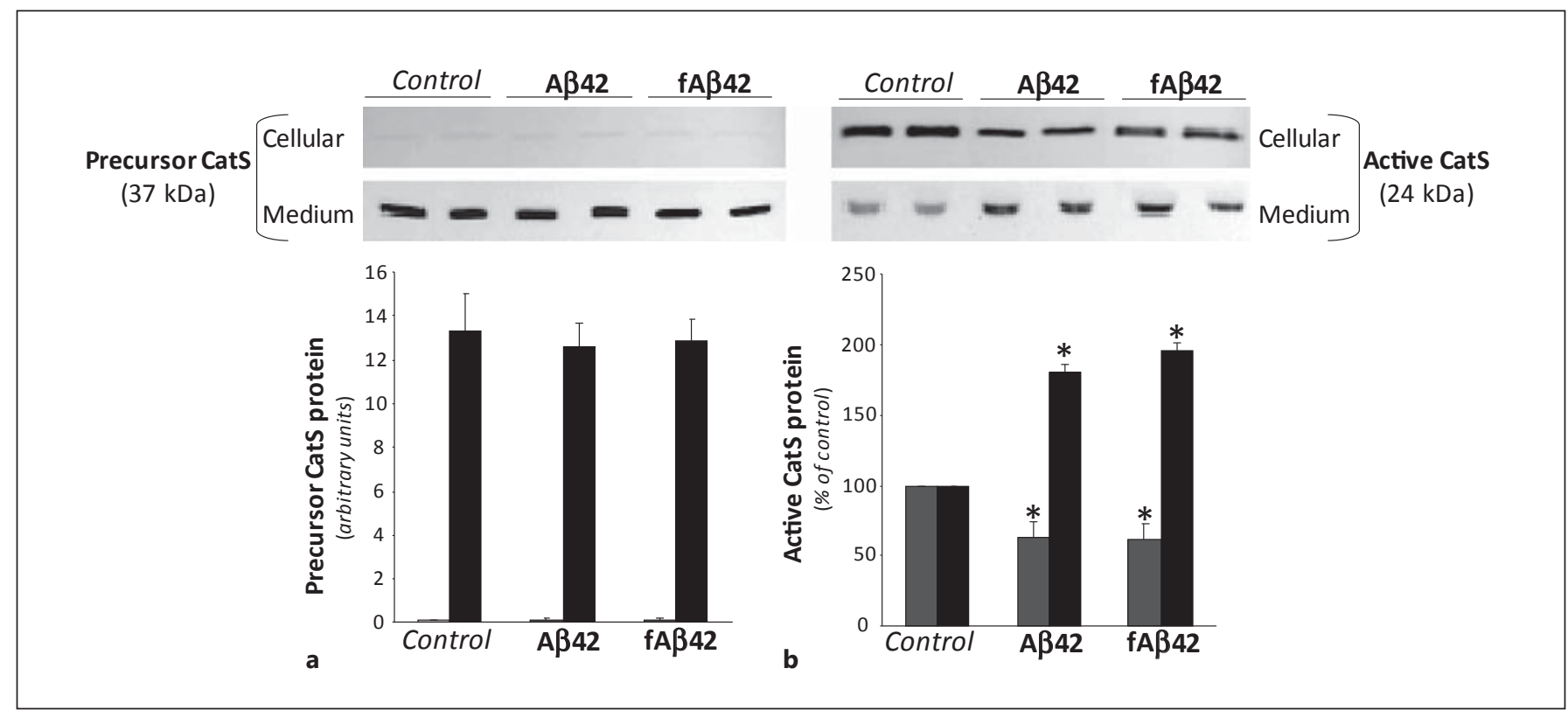

Fig. 4. Distribution of CatS in intracellular and extracellular fractions from control and HMDM exposed to A $\beta 42$ or fA $\beta 42$. HMDM were exposed to $A \beta 42$ or $\mathrm{fA} \beta 42(5 \mu \mathrm{M}, 48 \mathrm{~h})$ and collected for protein analysis. Representative Western blot analysis showing the precursor (a) and mature CatS (b) protein bands in HMDM and HMDM culture medium. Bar graphs show the quantification of precursor (a) and mature CatS (b) bands in control and $A \beta$ exposed HMDM (grey bars) and HMDM culture medium (black bars). Data are expressed as mean \pm SEM of three independent experiments performed in duplicate. ${ }^{*} \mathrm{p}<0.05$ versus control HMDM.

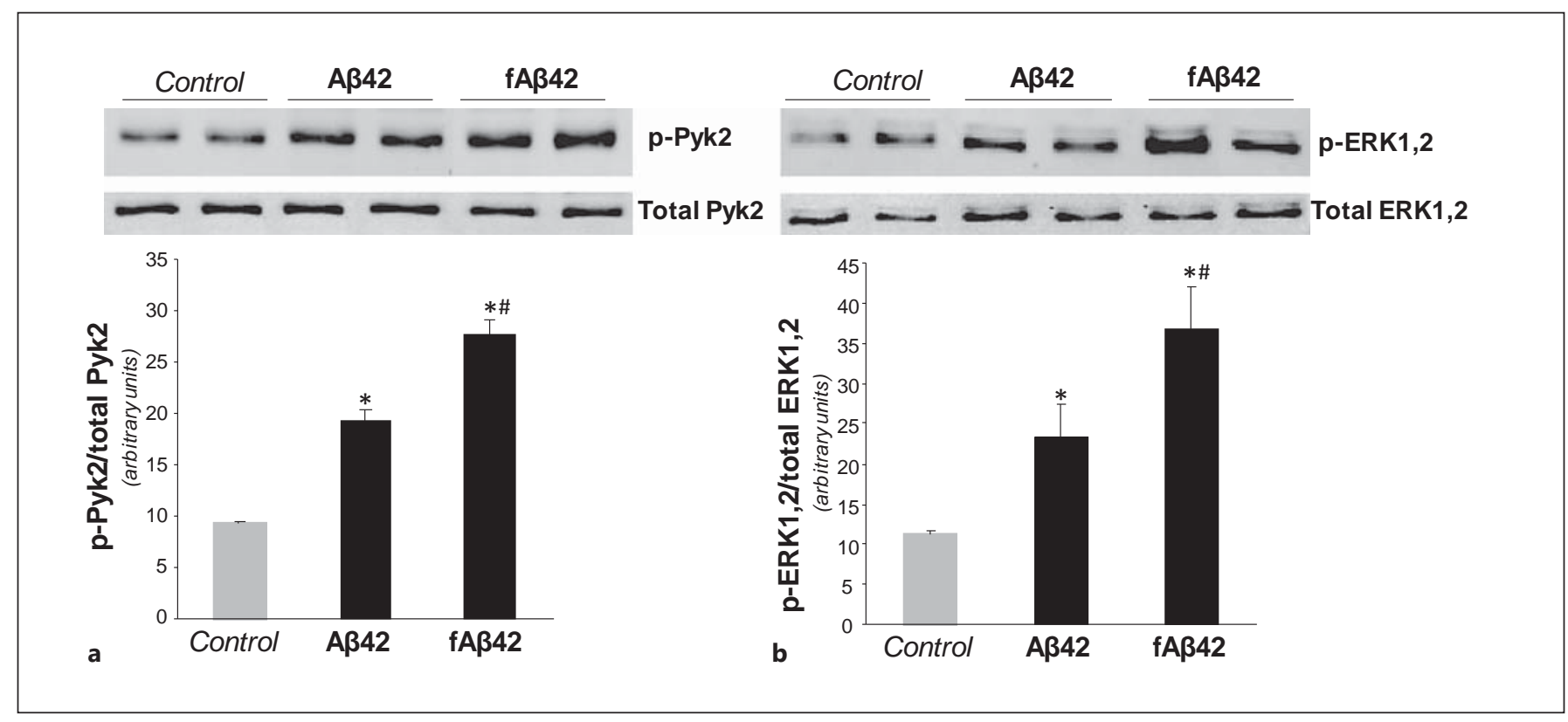

Fig. 5. Comparative effect of $A \beta 42$ and $\mathrm{fA} \beta 42$ on Pyk2 (a) and ERK1,2 (b) phosphorylation in human macrophages. HMDM were treated with $A \beta 42$ and $\mathrm{fA} \beta 42(5 \mu \mathrm{M})$ for $48 \mathrm{~h}$. Representative Western blot analysis showing LRP1, p-Pyk2, total Pyk2, p-ERK1,2 and total ERK1,2. Bar graphs represent quantification of specific
p-Pyk2 and p-ERK1,2 bands normalized by total Pyk2 and total ERK1,2, respectively. Results from two experiments performed in triplicate are expressed as mean \pm SEM. ${ }^{*} \mathrm{p}<0.05$ versus control cells (incubated in absence of $\mathrm{A} \beta 42$ ); ${ }^{\#} \mathrm{p}<0.05$ versus $\mathrm{A} \beta 42$ exposed HMDM. 


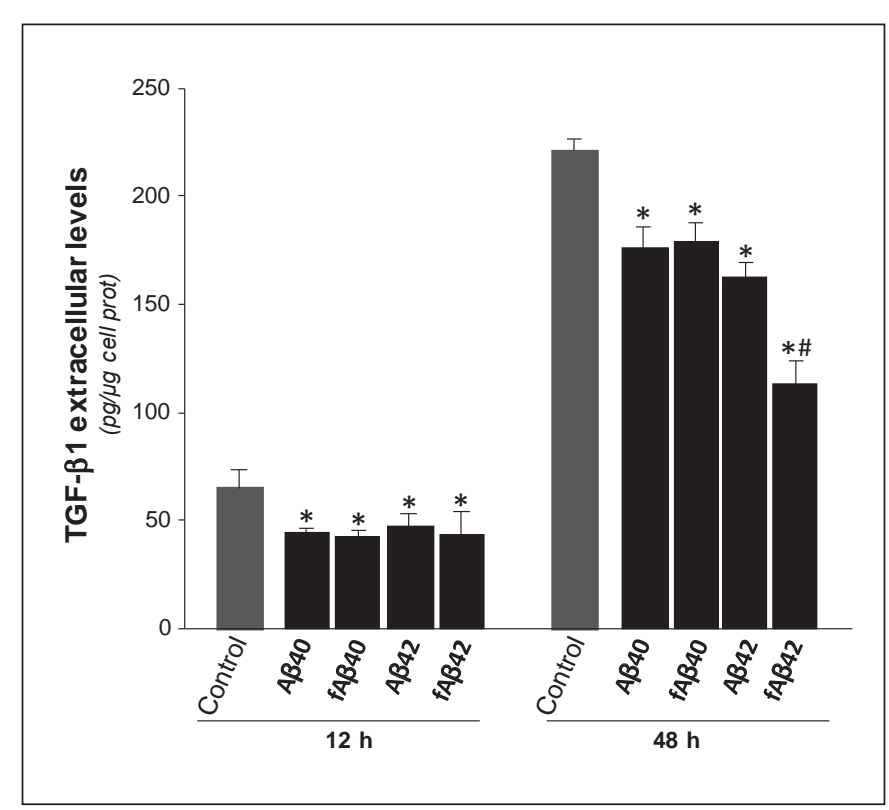

Fig. 6. Effect of $A \beta$ peptides on macrophage-secreted TGF- $\beta 1$ levels. HMDM were exposed to native and fibrillar forms of $\mathrm{A} \beta(5 \mu \mathrm{M})$ for 12 and $48 \mathrm{~h}$. Cell culture medium was collected and extracellular TGF- $\beta 1$ levels were determined by ELISA. Results are expressed as $\mathrm{pg} / \mu \mathrm{g}$ cell protein and shown as mean \pm SEM of four independent experiments performed in duplicate. ${ }^{*} \mathrm{p}<0.05$ versus control cells (incubated in absence of $\mathrm{A} \beta$ ); ${ }^{*} \mathrm{p}<0.05$ versus $\mathrm{A} \beta 42$ exposed HMDM.

\section{Discussion}

The main finding of the present study is that $A \beta$ strongly impacts macrophage metallo- and cysteine proteolytic activities and macrophage-TGF- $\beta 1$ secretion. Our study shows that $A \beta$ contributes to increase the macrophage-proinflammatory phenotype by increasing the levels of MMP-9/MMP-2 and CatS, and by reducing the levels of TGF- $\beta 1$ in the secretome of macrophages.

Results from the present study show that human macrophages can avidly internalize $A \beta$ and that this process has an effect on MMP-9 activation, in agreement with previous results in mice peritoneal macrophages [19]. However, our study shows that in human macrophages, in contrast to the results in mouse peritoneal macrophages, $A \beta$ peptides exerted an upregulatory effect not only on MMP-9, but also on MMP-2 expression and abundance. In fact, $A \beta$ peptides reportedly induce MMP9/MMP-2 activation in mixed rat hippocampal and enriched astrocyte cultures [38], but at higher dose $(20 \mu \mathrm{M})$ than that used in our study $(5 \mu \mathrm{M})$. In fact, we observed very little dose dependence and a strong effect at the low- est tested dose (10 nM) in our time-course experiments. These results suggest that human macrophages may have a limited capacity to internalize and degrade $A \beta$. In line with this hypothesis, it has been previously reported that adult microglia has lower capacity to take up and phagocytose $A \beta[39,40]$. In the present study, we also showed that $\mathrm{A} \beta$ negatively modulated TIMP-1 mRNA expression in HMDM. These results differ to those showing a positive effect of $A \beta$ peptides on TIMP levels in rat astrocytes [38]. Interestingly, the imbalance of MMPs over their tissue inhibitors in HMDM exposed to $\mathrm{A} \beta$ has been previously described in vascular cells exposed to other proatherosclerotic stimuli such as aggregated low-density lipoprotein [41] and also in tumoral cells [42]. Our data revealed that $\mathrm{fA} \beta 42$ was more efficient than $A \beta 42$, and $A \beta 42$ more efficient than $A \beta 40$ at increasing both MMP9 and MMP- 2 abundance, suggesting than less soluble $A \beta$ forms had higher ability to induce MMPs in human macrophages. In the present study we also showed that $A \beta$ activates Pyk2 and ERK1,2 phosphorylation in macrophages, as previously described in THP-1 cells [43], and human cortical neuronal cultures [44]. Previous studies have shown that Pyk2 phosphorylation may be involved in ERK1,2 activation $[45,46]$ and that the Pyk2-ERK1,2 signaling axis is involved in crucial processes such as cell proliferation and migration [45-47]. In relation to migration, previous studies reported the involvement of Pyk2/ ERK1,2 on MMP-3 [48] and MMP-13 [49] activation by fibronectin fragments in chondrocytes. Further studies are required to know whether Pyk2/ERK1,2 axis are also involved in the upregulatory effect of A $\beta$ on MMP-9/ MMP-2 expression and activity. The induction of metalloproteinase activity in macrophages reportedly induces atherosclerotic plaque disruption in different animal models [22]. Moreover, several studies in humans showed that MMP-9 overexpression strongly correlates with plaque instability and clinical manifestations of atherosclerosis [23-24]. Our study points to $A \beta$ as a critical inducer of both MMP-9 and MMP-2 expression and activation in human macrophages. Amyloid-like structures which accumulate in atherosclerotic lesions [7] induced protease activity in macrophages. Therefore, amyloid may be a potent contributor to extracellular matrix degradation linked to plaque rupture.

Cathepsins or lysosomal cysteine proteases, like other extracellular proteases, participate in extracellular matrix degradation in atherosclerosis. In atherosclerotic plaques, Cats $\mathrm{S}$ and $\mathrm{K}$ are overexpressed [50]. Moreover, CatS has been previously localized in intimal infiltrated macrophages [51]. CatS is localized on cell membranes but can 
also be secreted to the extracellular space. Results from the present study show that $\mathrm{A} \beta$ enhanced active CatS levels in the secretome of human macrophages. However, $\mathrm{A} \beta$ did not alter CatS mRNA expression, at least at $48 \mathrm{~h}$ of HMDM exposure to $A \beta$. These results may be explained by time-course differences in the $\mathrm{A} \beta$ modulation of CatS mRNA expression and CatS release in human macrophages. Previous studies have reported that macrophage-derived CatS in collaboration with MMP-9 degrade medial elastin [52]. Consistent with the elastolytic properties of CatS, CatS-deficient animals showed reduced fragmentation of elastic lamina in aortas of atherosclerotic lesions [30]. Elastin fragmentation reportedly induces fibrillar $A \beta$ formation [10-12]. Our results thus highlight the crucial role of $A \beta$ on extracellular matrix degradation and support the notion that the capacity of $\mathrm{A} \beta$ to induce metallo- and CatS activation in macrophages can create a positive feedback loop for $A \beta$ generation in the vascular wall, continuing directly in extracellular matrix degradation, plaque rupture and evolution of atherosclerosis to thrombosis. Results from the present study also highlight the crucial role of $A \beta$ peptides in the secretion of TGF- $\beta 1$ by human macrophages. Since macrophages are one of the main cellular sources of TGF- $\beta 1$, the exposure of macrophages to $A \beta$ may be, at least in part, the cause of TGF- $\beta 1$ reduction in advanced atherosclerotic plaques [31, 32]. In summary, our results highlight the crucial role of $A \beta$ on the modulation of macrophage protease activation and TGF- $\beta 1$ secretion, two key processes in plaque stability.

\section{Acknowledgments}

This work was made possible thanks to funding from FIS PI1 1/00747 from Instituto Salud Carlos III, cofinanced by Fondo Europeo de Desarrollo Regional (FEDER), MARATON TV3Malalties Cardiovasculars, PNS 2010/6549 and TERCEL RD06/0010/0017. The authors thank Laura Nasarre and Marta Sánchez for their technical support. L.B., V.L.L.C. and J.C. are members of the international graduate program PROMISE (IRTG-1566), supported by the Deutsche Forschungsgemeinschaft (Bonn, Germany).

\section{References}

1 Da Costa Dias B, Jovanovic K, Gonsalves D, Weiss SF: Structural and mechanistic commonalities of amyloid- $\beta$ and the prion protein. Prion 2011;5:126-137.

- Thinakaran G, Koo EH: Amyloid precursor protein trafficking, processing, and function. J Biol Chem 2008;283:29615-29619.

3 Haass C, Hung AY, Selkoe DJ: Processing of $\beta$-amyloid precursor protein in microglia and astrocytes favors an internal localization over constitutive secretion. J Neurosci 1991;11: 3783-3793.

4 Pimplikar SW: Reassessing the amyloid cascade hypothesis of Alzheimer's disease. Int J Biochem Cell Biol 2009;41:1261-1268.

5 Bitan G, Vollers SS, Teplow DB: Elucidation of primary structure elements controlling early amyloid $\beta$-protein oligomerization. J Biol Chem 2003;278:34882-34889.

-6 Teplow DB, Lazo ND, Bitan G, Bernstein S, Wyttenbach T, Bowers MT, Baumketner A, Shea JE, Urbanc B, Cruz L, Borreguero J, Stanley HE: Elucidating amyloid $\beta$-protein folding and assembly: a multidisciplinary approach. Acc Chem Res 2006;39:635-645.

7 Howlett GJ, Moore KJ: Untangling the role of amyloid in atherosclerosis. Curr Opin Lipidol 2006; 17:541-547.
8 Haggqvist B, Naslund J, Sletten K, Westermark GT, Mucchiano G, Tjernberg LO, Nordstedt C, Engstrom U, Westermark P: Medin: an integral fragment of aortic smooth muscle cell-produced lactadherin forms the most common human amyloid. Proc Natl Acad Sci USA 1999;96:8669-8674.

-9 Mucchiano GI, Haggqvist B, Sletten K, Westermark P: Apolipoprotein A-1-derived amyloid in atherosclerotic plaques of the human aorta. J Pathol 2001;193:270-275.

10 Kozel BA, Wachi H, Davis EC, Mecham RP: Domains in tropoelastin that mediate elastin deposition in vitro and in vivo. J Biol Chem 2003;278:18491-18498.

-11 Miao M, Bellingham CM, Stahl RJ, Sitarz EE, Lane CJ, Keeley FW: Sequence and structure determinants for the self-aggregation of recombinant polypeptides modeled after human elastin. J Biol Chem 2003;278:4855348562.

12 Tamburro AM, Lorusso M, Ibris N, Pepe A, Bochicchio $\mathrm{B}$ : Investigating by circular dichroism some amyloidogenic elastin-derived polypeptides. Chirality 2010;22(suppl 1):E56E66.

13 Roher AE, Kokjohn TA: Commentary on 'Alzheimer's disease drug development and the problem of the blood-brain barrier' - Alzheimer's disease drugs: more than one barrier to breach. Alzheimers Dement 2009;5:437438.
14 Bales KR, Dodart JC, DeMattos RB, Holtzman DM, Paul SM: Apolipoprotein E, amyloid, and Alzheimer disease. Mol Interv 2002;2: 363-375.

15 Blennow K, Hampel H: CSF markers for incipient Alzheimer's disease. Lancet Neurol 2003;2:605-613.

16 Haass C, Selkoe DJ: Cellular processing of $\beta$-amyloid precursor protein and the genesis of amyloid $\beta$-peptide. Cell 1993;75:10391042.

17 Selkoe DJ: Alzheimer's disease: a central role for amyloid. J Neuropathol Exp Neurol 1994; 53:438-447.

18 Verdier Y, Penke B: Binding sites of amyloid $\beta$-peptide in cell plasma membrane and implications for Alzheimer's disease. Curr Protein Pept Sci 2004;5:19-31.

19 Zhao L, Lin S, Bales KR, Gelfanova V, Koger D, Delong C, Hale J, Liu F, Hunter JM, Paul SM: Macrophage-mediated degradation of $\beta$-amyloid via an apolipoprotein $\mathrm{E}$ isoformdependent mechanism. J Neurosci 2009;29: 3603-3612.

20 Miners JS, Baig S, Palmer J, Palmer LE, Kehoe PG, Love S: A $\beta$-degrading enzymes in Alzheimer's disease. Brain Pathol 2008;18:240252. 
-21 Deguchi JO, Aikawa M, Tung CH, Aikawa E, Kim DE, Ntziachristos V, Weissleder R, Libby P: Inflammation in atherosclerosis: visualizing matrix metalloproteinase action in macrophages in vivo. Circulation 2006;114:5562.

-22 Gough PJ, Gomez IG, Wille PT, Raines EW: Macrophage expression of active MMP-9 induces acute plaque disruption in apoE-deficient mice. J Clin Invest 2006;116:59-69.

23 Blankenberg S, Rupprecht HJ, Poirier O, Bickel C, Smieja M, Hafner G, Meyer J, Cambien F, Tiret L: Plasma concentrations and genetic variation of matrix metalloproteinase 9 and prognosis of patients with cardiovascular disease. Circulation 2003;107:1579-1585.

24 Brown DL, Hibbs MS, Kearney M, Loushin C, Isner JM: Identification of $92-\mathrm{kD}$ gelatinase in human coronary atherosclerotic lesions: association of active enzyme synthesis with unstable angina. Circulation 1995;91:2125-2131.

-25 Rocken C, Tautenhahn J, Buhling F, Sachwitz D, Vockler S, Goette A, Burger T: Prevalence and pathology of amyloid in atherosclerotic arteries. Arterioscler Thromb Vasc Biol 2006; 26:676-677.

26 Riese RJ, Mitchell RN, Villadangos JA, Shi GP, Palmer JT, Karp ER, De Sanctis GT, Ploegh HL, Chapman HA: Cathepsin S activity regulates antigen presentation and immunity. J Clin Invest 1998;101:2351-2363.

-27 Nakagawa TY, Brissette WH, Lira PD, Griffiths RJ, Petrushova N, Stock J, McNeish JD, Eastman SE, Howard ED, Clarke SR, Rosloniec EF, Elliott EA, Rudensky AY: Impaired invariant chain degradation and antigen presentation and diminished collageninduced arthritis in cathepsin S null mice. Immunity 1999;10:207-217.

-28 Shi GP, Villadangos JA, Dranoff G, Small C, Gu L, Haley KJ, Riese R, Ploegh HL, Chapman HA: Cathepsin S required for normal MHC class II peptide loading and germinal center development. Immunity 1999;10:197-206.

29 Beers C, Honey K, Fink S, Forbush K, Rudensky A: Differential regulation of cathepsin $S$ and cathepsin 1 in interferon $\gamma$-treated macrophages. J Exp Med 2003;197:169-179.

-30 Sukhova GK, Zhang Y, Pan JH, Wada Y, Yamamoto T, Naito M, Kodama T, Tsimikas S, Witztum JL, Lu ML, Sakara Y, Chin MT, Libby P, Shi GP: Deficiency of cathepsin S reduces atherosclerosis in LDL receptor-deficient mice. J Clin Invest 2003;111:897-906.
31 McCaffrey TA, Du B, Fu C, Bray PJ, Sanborn TA, Deutsch E, Tarazona N, Shaknovitch A, Newman G, Patterson C, Bush HL Jr: The expression of TGF- $\beta$ receptors in human atherosclerosis: evidence for acquired resistance to apoptosis due to receptor imbalance. J Mol Cell Cardiol 1999;31:1627-1642.

32 Bobik A, Agrotis A, Kanellakis P, Dilley R, Krushinsky A, Smirnov V, Tararak E, Condron M, Kostolias G: Distinct patterns of transforming growth factor- $\beta$ isoform and receptor expression in human atherosclerotic lesions: colocalization implicates TGF- $\beta$ in fibrofatty lesion development. Circulation 1999; 99:2883-2891.

- 33 Stefoni S, Cianciolo G, Donati G, Dormi A, Silvestri MG, Coli L, De Pascalis A, Iannelli S: Low TGF- $\beta 1$ serum levels are a risk factor for atherosclerosis disease in ESRD patients. Kidney Int 2002;61:324-335.

-34 Tashiro H, Shimokawa H, Sadamatu K, Yamamoto K: Prognostic significance of plasma concentrations of transforming growth factor- $\beta$ in patients with coronary artery disease. Coron Artery Dis 2002;13:139-143.

35 Pike CJ, Burdick D, Walencewicz AJ, Glabe CG, Cotman CW: Neurodegeneration induced by $\beta$-amyloid peptides in vitro: the role of peptide assembly state. J Neurosci 1993;13: 1676-1687.

- 36 Jana A, Pahan K: Fibrillar amyloid- $\beta$ peptides kill human primary neurons via NADPH oxidase-mediated activation of neutral sphingomyelinase: implications for Alzheimer's disease. J Biol Chem 2004;279:51451-51459.

- 37 Schlenke P, Kluter H, Muller-Steinhardt M, Hammers HJ, Borchert K, Bein G: Evaluation of a novel mononuclear cell isolation procedure for serological HLA typing. Clin Diagn Lab Immunol 1998;5:808-813.

38 Deb S, Zhang JW, Gottschall PE: Activated isoforms of MMP-2 are induced in $\mathrm{u} 87 \mathrm{hu}$ man glioma cells in response to $\beta$-amyloid peptide. J Neurosci Res 1999;55:44-53.

39 Majumdar A, Chung H, Dolios G, Wang R, Asamoah N, Lobel P, Maxfield FR: Degradation of fibrillar forms of Alzheimer's amyloid $\beta$-peptide by macrophages. Neurobiol Aging 2008;29:707-715

40 Floden AM, Combs CK: $\beta$-Amyloid stimulates postnatal and adult microglia cultures in a unique manner. J Neurosci 2006;26:46444648.

41 Otero-Viñas M, Llorente-Cortes V, Peña E, Padro T, Badimon L: Aggregated LDL decrease metaloproteinase- 9 expression in human coronary smooth muscle cells. Atherosclerosis 2007;194:326-333.

-42 Giannelli G, Antonaci S: Gelatinases and their inhibitors in tumor metastasis: from biological research to medical applications. Histol Histopathol 2002;17:339-345.
43 Combs CK, Johnson DE, Cannady SB, Lehman TM, Landreth GE: Identification of microglial signal transduction pathways mediating a neurotoxic response to amyloidogenic fragments of $\beta$-amyloid and prion proteins. J Neurosci 1999;19:928-939.

44 Wright S, Malinin NL, Powell KA, Yednock T, Rydel RE, Griswold-Prenner I: $\alpha 2 \beta 1$ and $\alpha \mathrm{V} \beta 1$ integrin signaling pathways mediate amyloid- $\beta$-induced neurotoxicity. Neurobiol Aging 2007;28:226-237.

45 Sun CK, Man K, Ng KT, Ho JW, Lim ZX, Cheng Q, Lo CM, Poon RT, Fan ST: Prolinerich tyrosine kinase 2 (Pyk2) promotes proliferation and invasiveness of hepatocellular carcinoma cells through c-Src/ERK activation. Carcinogenesis 2008;29:2096-2105.

-46 Nicodemo AA, Pampillo M, Ferreira LT, Dale LB, Cregan T, Ribeiro FM, Ferguson SS: Pyk2 uncouples metabotropic glutamate receptor $\mathrm{G}$ protein signaling but facilitates ERK1/2 activation. Mol Brain 2010;3:4.

-47 Angelucci A, Bologna M: Targeting vascular cell migration as a strategy for blocking angiogenesis: the central role of focal adhesion protein tyrosine kinase family. Curr Pharm Des 2007;13:2129-2145.

48 Ding L, Guo D, Homandberg GA: Fibronectin fragments mediate matrix metalloproteinase upregulation and cartilage damage through proline rich tyrosine kinase 2, c-src, $\mathrm{NF}-\kappa \mathrm{B}$ and protein kinase $\mathrm{C} \delta$. Osteoarthritis Cartilage 2009;17:1385-1392.

49 Loeser RF, Forsyth CB, Samarel AM, Im HJ: Fibronectin fragment activation of prolinerich tyrosine kinase PYK2 mediates integrin signals regulating collagenase- 3 expression by human chondrocytes through a protein kinase C-dependent pathway. J Biol Chem 2003;278:24577-24585.

50 Sukhova GK, Shi GP, Simon DI, Chapman HA, Libby P: Expression of the elastolytic cathepsins $\mathrm{S}$ and $\mathrm{K}$ in human atheroma and regulation of their production in smooth muscle cells. J Clin Invest 1998;102:576-583.

51 Cheng XW, Kuzuya M, Sasaki T, Arakawa K, Kanda S, Sumi D, Koike T, Maeda K, TamayaMori N, Shi GP, Saito N, Iguchi A: Increased expression of elastolytic cysteine proteases, cathepsins $\mathrm{S}$ and $\mathrm{K}$, in the neointima of balloon-injured rat carotid arteries. Am J Pathol 2004;164:243-251.

52 Bouvet C, Moreau S, Blanchette J, de Blois D, Moreau P: Sequential activation of matrix metalloproteinase 9 and transforming growth factor $\beta$ in arterial elastocalcinosis. Arterioscler Thromb Vasc Biol 2008;28:856-862.
$\mathrm{A} \beta$ Increases Protease Activity in Macrophages
J Vasc Res 2014;51:58-67

DOI: $10.1159 / 000356334$ 